Acta Technologica Agriculturae 1

Nitra, Slovaca Universitas Agriculturae Nitriae, 2019, pp. 5-11

\title{
EFFICIENCY COMPARISON OF DIFFERENT PHOTOVOLTAIC MODULES
}

\author{
Atsu Divine KAFUI*, István SERES, István FARKAS \\ Szent István University, Gödöllő, Hungary
}

\begin{abstract}
Solar photovoltaic power generation capacity is rising continuously as a result of various regional, sub-regional renewable energy policies and the impact of technology development, as well as the increasing environmental concerns. Characteristics of photovoltaic modules are provided by manufacturers after they have been tested indoors under standard test conditions. These parameters may vary under exterior conditions. It is thus imperative to establish the quantity of the energy produced by photovoltaic modules under real operation conditions. This study sought to assess the performance of different kinds of photovoltaic module technologies in the city of Gödöllö, Hungary, and ascertain the behaviour of the modules under real outdoor conditions. Modules include amorphous silicon (a-Si), monocrystalline silicon (mc-Si), polycrystalline silicon (pc-Si), transparent monocrystalline silicon module (mc-Si). Measurement of the module characteristics was performed and various meteorological parameters were obtained. Performance parameters such as performance ratio and efficiency are given and analysed. Module temperature was estimated and evaluated in comparison with experimental values. Energy conversion rates of the modules were determined as 9.4\%, 4.4\%, 10.3\%, 8.2\% and 10.4\% for mc-Si module transparent glass (165 Wp), a-Si module (glass 40Wp), pc-Si module (105 Wp), pc-Si module $(60 \mathrm{Wp})$ and mc-Si (PV-T $180 \mathrm{Wp})$, respectively. Under the given outdoor conditions, the highest average performance ratio of $85.2 \%$ was obtained for the mc-Si module (transparent glass, $165 \mathrm{Wp}$ ), exhibiting the best performance, while pc-Si module $(60 \mathrm{Wp})$ showed the least average performance ratio of $71.8 \%$.
\end{abstract}

Keywords: photovoltaic technologies; energy yield; field performance; energy conversion rate

The Sun, a silent, free and non-polluting source of energy, is responsible for all forms of life on earth. Sun's harnessable energy is endless in the nearest foreseeable time, both as a source of heat and light. Without doubt, it is one of the most promising energy source alternatives for meeting the challenges of this millennium. Sunlight, which is available everywhere on the Earth, is virtually responsible for all other energy sources. Therefore, energies from the other energy sources are virtually derived from the Sun.

Solar PV (photovoltaics) has become a ubiquitous source of renewable energy (Bilčík et al., 2018). Solar PV power market is increasing continuously as a result of the various regional, sub-regional and country renewable energy policy schemes. Other factors accounting for this expansion include the depleting status of fossils fuels caused by the increasing energy demand, impact of technology development, lower cost of technology and environmental concerns.

Data sheets of PV modules provide characteristics that are determined by manufacturers in an interior laboratory under a controlled STC (standard test conditions), which include a cell temperature of $25^{\circ} \mathrm{C}$, radiation intensity of $1,000 \mathrm{~W} \cdot \mathrm{m}^{-2}$ and air mass AM1.5. Not only spectral reactions, temperature coefficients, voltage and current values of individual solar cells and module types differ, but their reactions to environmental factors like radiation, temperature and wind speed vary as well. However, solar spectrum varies depending on geographical location (Atsu et al., 2017).
There is an increase in the diversity of available technologies of solar cells integrated in PV modules - from thin films to crystalline silicon, which still dominates the market with nearly $90 \%$ (IEA, 2014). The most common PV module types currently available have energy efficiencies of approximately (7-11)\% a-Si and (14-19)\% (c-Si, single or double face). Other available module type is triple-junction PV with concentrating lenses with energy efficiency approximately (23-27)\%. Future multi-junction cell structures are expected to increase the average efficiency from current $40 \%$ to over $50 \%$ (King et al., 2012). To choose a particular technology of solar module for an individual site, it is important to establish the energy yield of the module under real meteorological conditions of the specific location.

Studies by Singh (2013), Carr and Pryor (2004), Del Cueto (2002), Cañete et al. (2014) and Balaska et al. (2017) show the dependence of PV energy efficiency and final power output on conditions that deviate from STC for different mounting geometries and PV materials extending the range of useful predictions of PV cells performance.

Majority of these relationships are either theoretical or semi empirical, founded on laboratory measurements, and as a result, they do not incorporate the entire range of interdependencies between the various environmental factors. These, however, may have a pronounce effect on the actual PV efficiency and power output (Durisch et al., 2007). 
Table 1 Geographical site parameters for Gödöllő (PVsyst 6.7.0)

\begin{tabular}{|c|c|c|c|c|}
\hline Period & $\begin{array}{l}\text { Global irradiation } \\
\left(\mathrm{kWh} \cdot \mathrm{m}^{-2} \cdot \mathrm{d}^{-1}\right)\end{array}$ & $\begin{array}{l}\text { Diffuse irradiation } \\
\left(\mathrm{kWh} \cdot \mathrm{m}^{-2} \cdot \mathrm{d}^{-1}\right)\end{array}$ & $\begin{array}{c}\text { Temperature } \\
\left({ }^{\circ} \mathrm{C}\right)\end{array}$ & $\begin{array}{l}\text { Wind speed } \\
\left(\mathrm{m} \cdot \mathrm{s}^{-1}\right)\end{array}$ \\
\hline January & 0.97 & 0.69 & -0.6 & 2.78 \\
\hline February & 1.84 & 0.94 & 1.1 & 3.00 \\
\hline March & 2.93 & 1.46 & 5.6 & 3.41 \\
\hline April & 4.41 & 2.08 & 11.7 & 3.10 \\
\hline May & 5.53 & 2.44 & 17.1 & 2.99 \\
\hline June & 5.99 & 3.00 & 19.6 & 2.89 \\
\hline July & 5.98 & 2.85 & 21.8 & 3.09 \\
\hline August & 5.00 & 2.22 & 21.3 & 2.71 \\
\hline September & 3.60 & 1.81 & 15.6 & 2.61 \\
\hline October & 2.31 & 1.19 & 11.3 & 2.6 \\
\hline November & 1.14 & 0.73 & 5.7 & 3.00 \\
\hline December & 0.81 & 0.51 & 0.2 & 2.49 \\
\hline Year average & 3.38 & 1.66 & 10.9 & 2.49 \\
\hline
\end{tabular}

Considering this area, multiple studies have been conducted in different locations to assess the impact of environmental factors on the performance of different cell technologies or numerous studies have set their goals to determine the best operation conditions for the specific sites.

Study by Ye et al. (2014) evaluates the performance of a-Si and mc-Si modules according to radiation distribution, temperature and other external environment factors authors observed that a-Si modules were more efficient in the blue rich spectrum, whereas the mc-Si modules showed efficiency varying with changes in cell temperature. Sharma et al. (2013) evaluated different on-grid PV systems with arrays of different module technologies in India. They concluded that systems with a-Si and HIT modules showed better results than pc-Si modules.

Cañete et al. (2014) performed a comparative study under meteorological conditions in Southern Spain on four different PV module technologies: a-Si, tandem structure

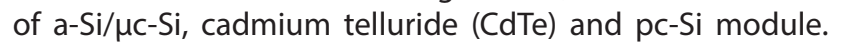
Results of their study showed that performance of thin film modules is better than that of pc-Si modules for this location.

Basoglu et al. (2015) compared the energy performance of three different PV module technologies under Izmit, Kocaeli climatic conditions in Turkey. Module technologies were $\mathrm{mc}-\mathrm{Si}, \mathrm{c}-\mathrm{Si}$ and $\mathrm{CdTe}$. They concluded that $\mathrm{CdTe}$ modules are more acceptable for climatic condition in Izmit.

Aforementioned studies have shown that each of the PV technologies has unique merits and limitations in operation under various climatic conditions (Cristina et al., 2014).

The amount of usable solar radiation at any site is dependent on the angle of inclination and equipment orientation, as well as on intensity of total solar radiation. In comparison to other European countries, Hungary has more favourable conditions for PV. Annual sunshine hours range between 1,900 and 2,200 hours. Annual average global irradiation of Gödöllő is approximately $3.38 \mathrm{kWh} \cdot \mathrm{m}^{-2} \cdot \mathrm{d}^{-1}$ and diffuse irradiation is $1.66 \mathrm{kWh} \cdot \mathrm{m}^{-2} \cdot \mathrm{d}^{-1}$ (Table 1 ). This makes
Hungary an appropriate location for the utilization of solar energy for energy generation.

Our study aims to assess the performance of different kinds of PV module technologies (a-Si, mc-Si, pc-Si, transparent mc-Si) under real outdoor conditions. Performance parameters, such as performance ratio and efficiency, are given and analysed.

\section{Material and methods}

\section{Experimental setup}

Experimental setup was located at the Solar Energy Laboratory of the Szent István University, Gödöllö, Hungary situated at latitude $47^{\circ} 35^{\prime} 39^{\prime \prime} \mathrm{N}$, longitude $19^{\circ} 22^{\prime} 0^{\prime \prime} \mathrm{E}$. PV modules types used and their specifications under laboratory STC are summarized in Table 2. PV modules were inclined to a fixed physical support outside the lab and oriented to the south with an inclination corresponding to the site latitude. The modules' output power, voltage and current were measured automatically using the Geräte Unterricht Naturwissenschaft Technik (G.U.N.T) PV setup as shown in Fig. 1. Solar radiation was measured with a Kimo solarimeter LSL 200 at the level and inclination of the PV modules (resolution $1 \mathrm{~W} \cdot \mathrm{m}^{-2}$, accuracy $5 \%$ ). Temperature of PV modules, ambient temperature of $\mathrm{PV}$ modules and ambient temperature were measured using HT-9815 Xintest Pt-100 sensors $\left( \pm 0.1^{\circ} \mathrm{C}\right)$.

\section{Performance analysis}

Performance of individual modules was evaluated in accordance the IEC standard (IEC 61724) describing the parameters of solar modules. Certain parameters like yield, performance ratio efficiency, were calculated.

\section{Module yield}

Specific module yield $\left(Y_{a}\right)$ is defined as the ratio of the energy output from the module to a particular duration to its rated power: 

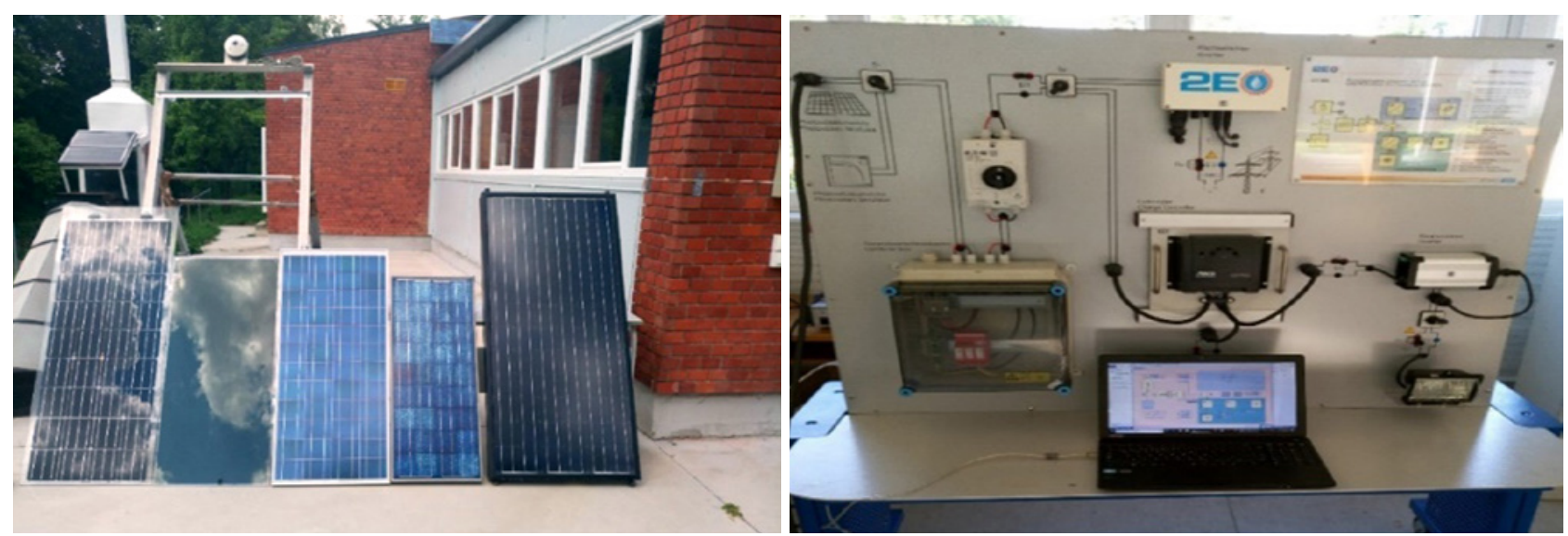

Fig. 1 PV modules and experimental setup for data collection

Table 2 Technical specifications of PV modules under STC

\begin{tabular}{|c|c|c|c|c|c|}
\hline Parameters & $\begin{array}{c}\text { a-Si (Glass) } \\
\text { (DUNA SOLAR) }\end{array}$ & $\begin{array}{l}\text { mc-Si (Glass) } \\
\text { (SOLARWATT) }\end{array}$ & $\begin{array}{c}\text { pc-Si (60Wp) } \\
\text { (SOLAREX SM2160) }\end{array}$ & $\begin{array}{c}\text { pc-Si (105Wp) } \\
\text { (RWE SCHOTT SOLAR) }\end{array}$ & $\begin{array}{c}\text { PV-T glazed } \\
\text { (mc-Si) (SOLIMPEKS) }\end{array}$ \\
\hline$V_{o c}(\mathrm{~V})$ & 62.5 & 23.4 & 21.3 & 29.5 & 43.39 \\
\hline$I_{s c}(\mathrm{~A})$ & 1.15 & 9.02 & 3.8 & 4.92 & 5.55 \\
\hline$V_{m p p}(\mathrm{~V})$ & 44.0 & 19.2 & 17.1 & 23.5 & 35.15 \\
\hline$I_{m p p}(A)$ & 0.90 & 8.71 & 3.5 & 4.47 & 5.12 \\
\hline$P_{m p p}(\mathrm{Wp})$ & 40 & 165 & 60 & 105 & 180 \\
\hline Module area $\left(\mathrm{m}^{2}\right)$ & 0.791 & 1.62 & 0.564 & 0.826 & 1.427 \\
\hline Temp. coeff. of power & -0.47 & $-0.40 \% /{ }^{\circ} \mathrm{C}$ & -0.47 & $-0.47 \% /{ }^{\circ} \mathrm{C}$ & $-0.45 \% /{ }^{\circ} \mathrm{C}$ \\
\hline Temp. coeff. of $V_{\text {oc }}$ & $-0.36 \% /$ & $-0.32 \% /{ }^{\circ} \mathrm{C}$ & $-0.073 \% /{ }^{\circ} \mathrm{C}$ & $-0.38 \% /{ }^{\circ} \mathrm{C}$ & $-0.34 \% /{ }^{\circ} \mathrm{C}$ \\
\hline Temp. coeff. of $l_{s c}$ & $+0.04 \% /$ & $0.05 \% /{ }^{\circ} \mathrm{C}$ & $0.003 \% /{ }^{\circ} \mathrm{C}$ & $+0.10 \% /{ }^{\circ} \mathrm{C}$ & $+0.06 \% /{ }^{\circ} \mathrm{C}$ \\
\hline Efficiency & $5 \%$ & $10.3 \%$ & $10.6 \%$ & $12.7 \%$ & $12.6 \%$ \\
\hline
\end{tabular}

PV-T - photovoltaic thermal, $V_{o}$ - open circuit voltage, $I_{s c}$ - short circuit current

$$
Y_{a}=\frac{E_{D C}}{P_{P V_{\text {rated }}}}
$$

\section{Solar module temperature}

Considering the calculation of the module temperature $\left(T_{c}\right)$, following model is used:

$$
T_{c}=T_{a}+\frac{G}{G_{\text {STC }}} \times\left(T_{\text {NOCT }}-20\right)
$$

where:

$T_{a} \quad$ - ambient temperature $\left({ }^{\circ} \mathrm{C}\right)$

$T_{\text {NOCT }}$ - nominal operating cell temperature given by the manufacturer $\left({ }^{\circ} \mathrm{C}\right)(\mathrm{NOCT}$ - nominal operating cell temperature)

$G \quad$ - measured solar irradiation over the surface of the module (W.m ${ }^{-2}$ ) (Duffie and Beckman, 2006)

\section{Solar module output power}

Solar module output power is calculated from the model taking into account the linear dependence of output power on the solar irradiance and cell temperature. It is given by Eq. (3):

$$
P_{m}=P_{m S T C} \times \frac{G}{G_{S T C}} \times\left(1-\gamma\left(T_{C}-25\right)\right)
$$

where:

$P_{m} \quad$ - calculated output power (W)

$P_{\text {m.STC }}$ - maximum rated power at STC given by the manufacturer (W)

$G \quad$ - solar radiation intensity on the plane of the module $\left(\mathrm{W} \cdot \mathrm{m}^{-2}\right)$

$G_{\text {STC }}$ - solar radiation intensity of $1,000 \mathrm{~W} \cdot \mathrm{m}^{-2}$

$\gamma$ - maximum power correction factor for temperature

$T_{c} \quad-$ module temperature $\left({ }^{\circ} \mathrm{C}\right)$

\section{Solar module efficiency}

Instantaneous efficiency of the module is defined as follows:

$$
\eta=\frac{P}{(G \times A)}
$$

where:

$$
\begin{aligned}
\eta & - \text { efficiency (\%) } \\
P & - \text { measured power output }(\mathrm{W}) \\
G \quad- & \text { measured solar irradiation }\left(\mathrm{W} \cdot \mathrm{m}^{-2}\right) \\
A- & \text { suarface area of the module }\left(\mathrm{m}^{2}\right) \text { (Duffie and } \\
& \text { Beckman, 2006) }
\end{aligned}
$$


However, model given by Eq. (5) is necessary for calculation of instantaneous efficiency:

$$
\eta=\eta_{\text {Tref }}\left(1-\beta_{\text {ref }}\left(T_{c}-T_{\text {ref }}\right)+\gamma \lg G_{T}\right)
$$

where:

$$
\begin{aligned}
& \eta \quad \text { instantaneuos efficiency; } \\
& \eta_{\text {Tref }}-\text { efficiency at the reference condition (\%) } \\
& \beta_{\text {ref }}-\text { temperature coefficient } \\
& T_{\text {ref }} \quad-\text { temperature at the reference condition }\left({ }^{\circ} \mathrm{C}\right) \\
& T_{c}-\text { solar module temperature }\left({ }^{\circ} \mathrm{C}\right) \\
& \gamma \quad-\text { correction factor for the irradiance } \\
& G_{T}-\text { solar irradiance intensity }\left(\mathrm{W} \cdot \mathrm{m}^{-2}\right)(\text { Almonacid et al., } \\
& \quad \text { 2011) }
\end{aligned}
$$

However, following module is used for the majority of c-Si modules:

$$
\eta=\eta_{\text {Tref }}\left(1-\beta_{\text {ref }}\left(T_{c}-T_{\text {ref }}\right)\right)
$$

where:

$$
\begin{aligned}
& \eta \quad \text { - instantaneuos efficiency } \\
& \eta_{\text {Tref }}-\text { efficiency at the reference condition (\%) } \\
& T_{\text {ref }}-\text { temperature at the reference condition }\left({ }^{\circ} \mathrm{C}\right) \\
& \beta_{\text {ref }}-\text { temperature coefficient } \\
& T_{c}-\text { solar module temperature }\left({ }^{\circ} \mathrm{C}\right)
\end{aligned}
$$

\section{Performance ratio (PR)}

Performance ratio is the ratio of the PV module/system efficiency during operation to its efficiency at STC as given by Eq. (7):

$$
P R=\frac{\eta_{\text {syst }}}{\eta_{\text {STC }}}
$$

PR shows the closeness of a PV system to the ideal performance during real operation conditions and allows comparison of PV systems independently of location, tilt angle, orientation and their nominal rated power capacity (Ayompe et al., 2011).

\section{Results and discussion}

This part explains the measured data obtained during the experiment in detail and compares measured data for the individual modules with the characteristics given by manufacturer.

Incident radiation onto the modules was quite stable throughout the period of the experiment. Maximum value observed was $965 \mathrm{~W} \cdot \mathrm{m}^{-2}$ and minimum value recorded was $915 \mathrm{~W} \cdot \mathrm{m}^{-2}$ with an average radiation of $935 \mathrm{~W} \cdot \mathrm{m}^{-2}$ as shown in Fig. 2. Ambient temperature and module temperature measured are shown in Fig. 3. Results indicate a maximum ambient temperature of $37^{\circ} \mathrm{C}$ and an average temperature of $35^{\circ} \mathrm{C}$ for the experiment duration.

The pc-Si $(105 \mathrm{Wp})$ module had the highest recorded temperature $\left(61^{\circ} \mathrm{C}\right)$ during the experiment. Minimum temperature of $54.7^{\circ} \mathrm{C}$ was observed in the mc-Si (165Wp) glass module. Average temperatures of the various modules were $57.7^{\circ} \mathrm{C}, 58.9^{\circ} \mathrm{C}, 58.7^{\circ} \mathrm{C}$, and $58.0^{\circ} \mathrm{C}$ for mc-Si $165 \mathrm{Wp}$

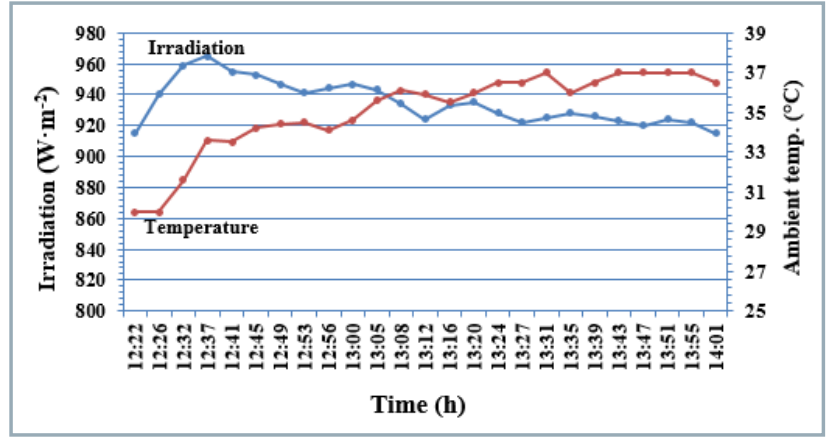

Fig. 2 Variation in ambient temperature with irradiation

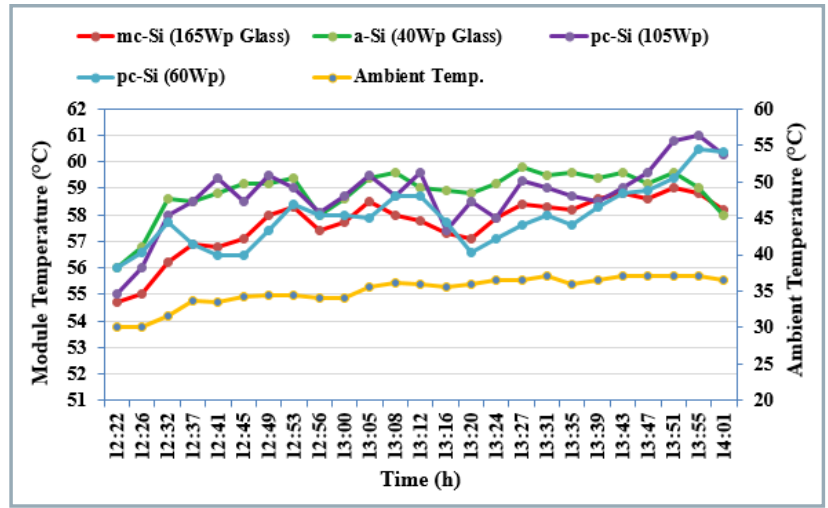

Fig. 3 Trends in module and ambient temperatures

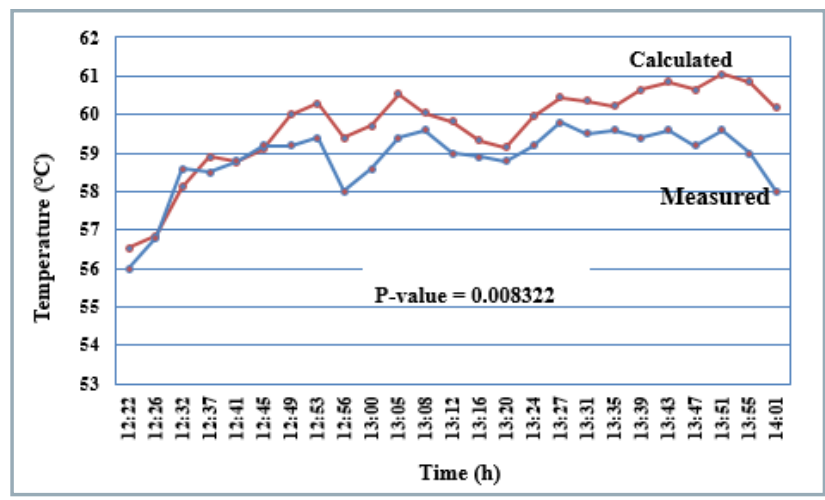

Fig. 4 Comparison between calculated and measured module temp. a-Si (40 Wp Glass)

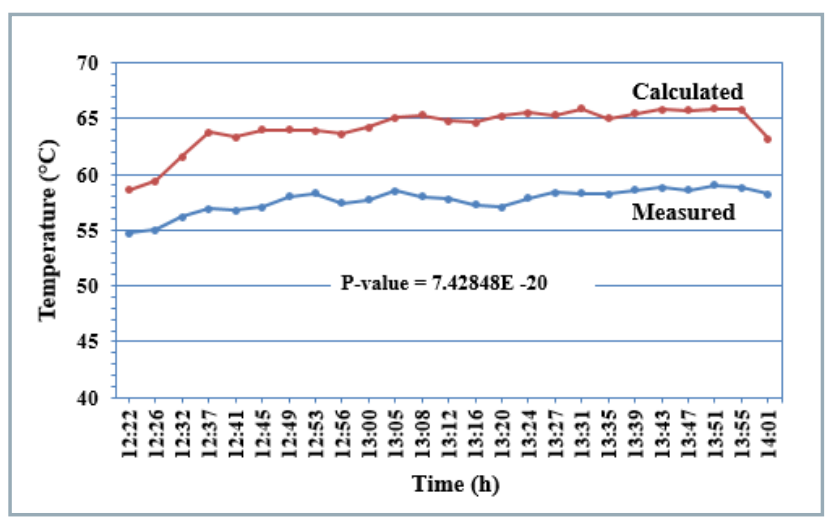

Fig. 5 Comparison between calculated and measured module temp. (mc-Si -165 Wp Glass) 
glass, a-Si 40Wp Glass, pc-Si, 105Wp, pc-Si 60Wp respectively. Maximum average value of $58.87^{\circ} \mathrm{C}$ was observed in the a-Si $40 \mathrm{Wp}$ glass module and minimum average temperature of $57.77^{\circ} \mathrm{C}$ was observed in mc-Si $165 \mathrm{Wp}$ glass module.

As Figs. 4, 5, 6, and 7 show, calculated average module temperature was $58.76{ }^{\circ} \mathrm{C}$. Subsequently, minimum and maximum values were $55.64^{\circ} \mathrm{C}$ and $60.16^{\circ} \mathrm{C}$ respectively.

Measured temperatures for mc-Si (165 Wp Glass) were lower than the calculated module temperatures throughout the entire experiment as shown in Fig. 5. Mc-Si (165 Wp Glass) also showed the highest significant deviation between the measured and calculated values. With the exception of the pc-Si (105 Wp), which showed no significant difference between the measured and calculated temperatures, the mc-Si (165 Wp glass), a-Si (40 Wp) and pc-Si (60 Wp) had significant deviations as shown by their $P$-values. The greatest deviation was observed in the mc-Si $-165 \mathrm{Wp}$ module.

Measured average temperatures for the modules were $57.66 ; 58.87 ; 58.74$ and $57.93^{\circ} \mathrm{C}$ for mc-Si ( $165 \mathrm{Wp}$ glass), a- $\mathrm{Si}$ (40 Wp), pc-Si (105 Wp) and pc-Si (60 Wp) respectively. Each module showed a different trend of measured temperatures corresponding with the calculated module temperatures as shown in Figs. 4, 5, 6, and 7.

Fig. 8 demonstrates the module efficiencies with variation in irradiation levels - initial high efficiency values of all modules are as a result of increasing irradiation (for initial 20 minutes). Subsequently, after this point, there is a gradual decrease in irradiation with corresponding decrease in efficiency for all the modules.

Figs. 9, 10, 11 and 12 present the relationships between the efficiencies and module temperatures. Results show a corresponding decrease in efficiency for all studied modules with increases in the module temperatures.

However, this trend of efficiency decreasing is not smoothly continuous. Corresponding effect of change in temperature of the module, whether increasing or decreasing, can be seen in the varying efficiency of the modules. However, for the pc-Si (105 Wp) module, the efficiency of the module began to increase with increase in module temperature at module temperature $\geq 58^{\circ} \mathrm{C}$.

Table 3 compares the efficiencies determined by experimental data with manufacturer's values.

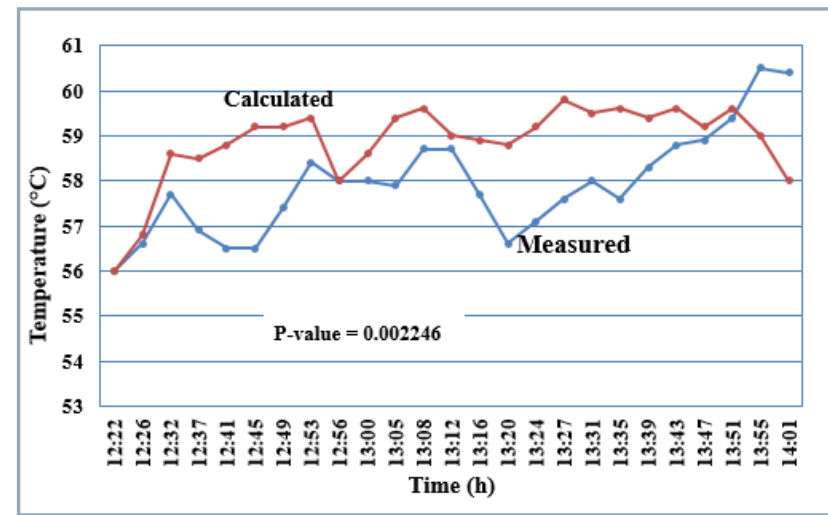

Fig. 6 Comparison between calculated and measured module temp. pc-Si (60Wp)

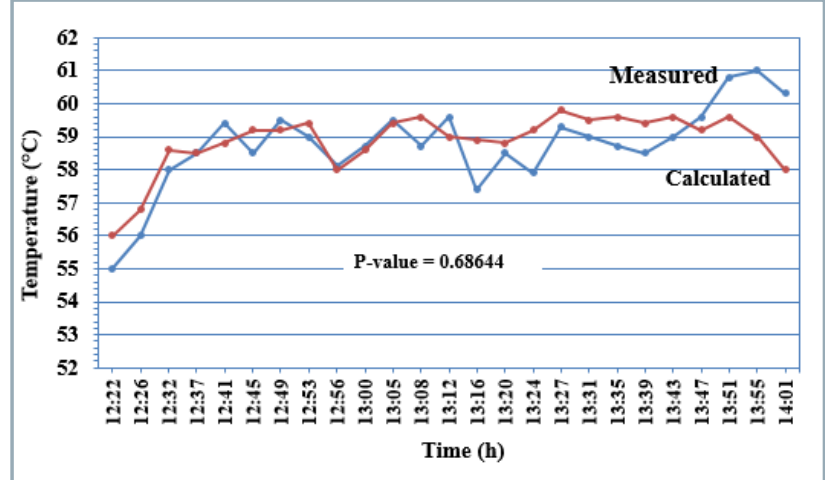

Fig. 7 Comparison between calculated and measured module temp. pc-Si (105Wp)

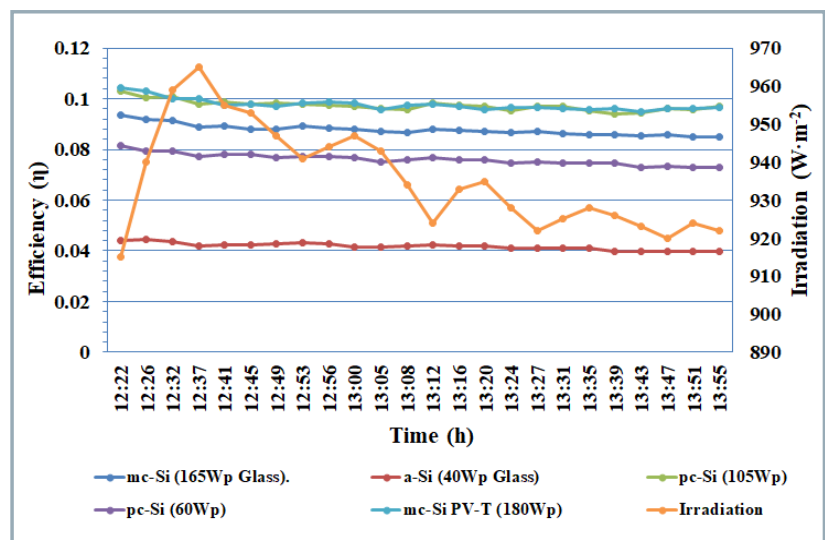

Fig. 8 Variation of efficiency of modules with irradiation

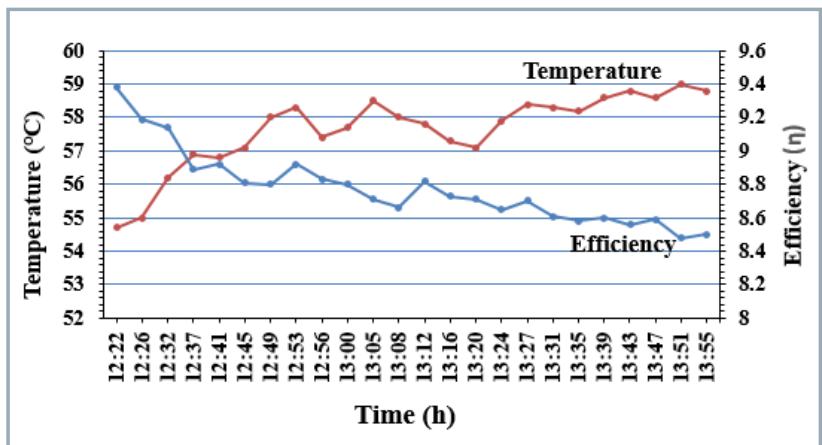

Fig. 9 Relationship between efficiency and temperature of module mc-Si (165 Wp Glass)

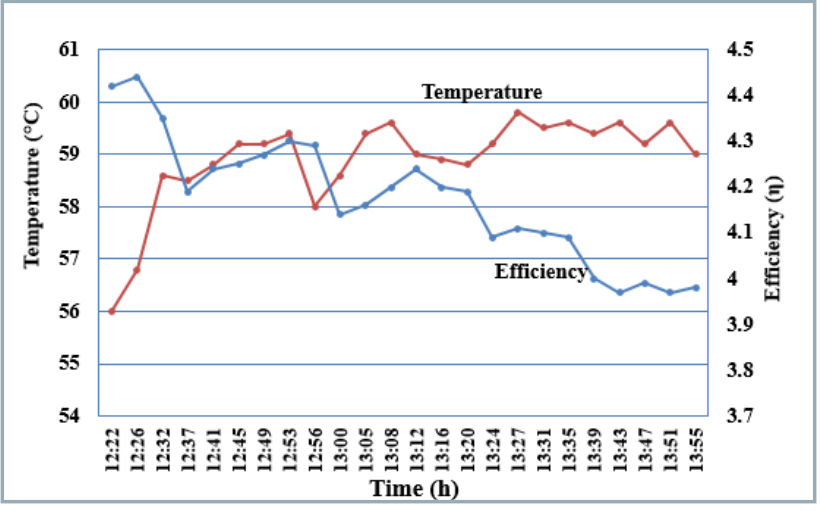

Fig. 10 Relationship between efficiency and temperature of module a-Si (40Wp Glass) 


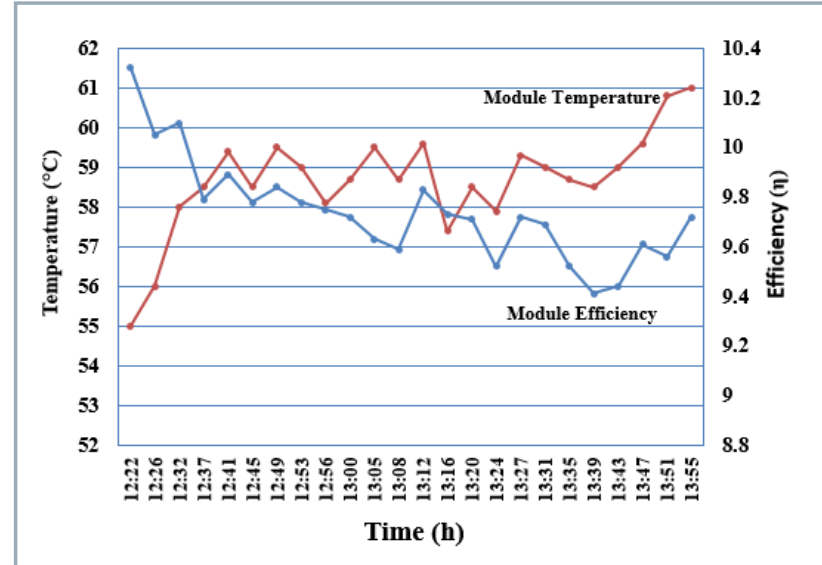

Fig. 11 Relationship between efficiency and temperature of module pc-Si (105 Wp)

Results show varying deviations depending on the technology. As shown in Table 3, the highest deviation from the manufacturer's values was 2.4, obtained for pc-Si module $(60 \mathrm{Wp})$, while the lowest deviation from the given manufacturer's efficiencies was 0.6 , obtained for a-Si module $(40 \mathrm{Wp})$. It is worth mentioning that this module has already been in operation for approximately 20 years. However, the highest percentage deviation of $-22.6 \%$ was recorded for the pc-Si module $(60 \mathrm{Wp})$, while the minimum percentage deviation of $-8.7 \%$ was obtained for the mc-165 Wp transparent module as shown in Table 3 . In literature, results by Balaska et al. (2017) indicated daily mean efficiencies of $8.38 \%$ and $12.63 \%$ for $\mathrm{m}-\mathrm{Si} \_\mu \mathrm{c}-\mathrm{Si}$, and $\mathrm{mc}-\mathrm{Si}$, respectively. Cañete et al. (2014) also recorded an efficiency of $9.3 \%$ for $\mathrm{CdTe}, 6.3 \%$ for a-Si, $13.2 \%$ for pc-Si and $8.0 \%$ for a-Si/ $\mu \mathrm{mc}-\mathrm{Si}$. Determining the percentage deviation between the manufacturer's values and the experimentally obtained efficiency, Cañete et al. (2014) recorded $-4.1 \%$ deviation for CdTe, $-4.8 \%$ for a-Si, $-5.9 \%$ for a-Si/ $\mu \mathrm{mc}-\mathrm{Si}$ and $-1.5 \%$ for $\mathrm{pc}-\mathrm{Si}$.

The performance ratios for the modules are presented in Table 4. The mc-Si transparent glass module (165 Wp)

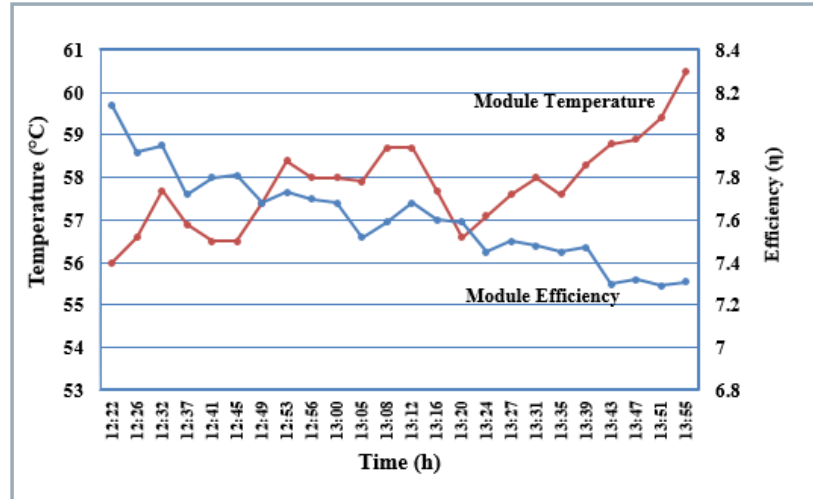

Fig. 12 Relationship between efficiency and temperature of module pc-Si $(60 \mathrm{Wp})$

showed the highest average performance ratio PR of $85.2 \%$. The lowest average PR of $71.8 \%$ was obtained for $\mathrm{pc}-\mathrm{Si}$ module (60 Wp).

Average PR of $82.6 \%, 77.5 \%$, and $76.7 \%$ were recorded for a-Si module (glass $40 \mathrm{Wp}$ ), PV-T (180 Wp) and pc-Si module (105 Wp), respectively. Cañete et al. (2014), however, observed an annual average PR of $94.8 \%$ for a-Si, $92.9 \%$ for pc-Si, and $93.9 \%$ for a-Si/ $\mu \mathrm{mc}-\mathrm{Si}$.

\section{Conclusions}

Performance analyses were carried out for five different modules under the same outdoor conditions. Modules were exposed to an average irradiation of $935 \mathrm{~W} \cdot \mathrm{m}^{-2}$ and average ambient temperature of $35^{\circ} \mathrm{C}$. Energy conversion rates of the modules were determined as $9.4 \%, 4.4 \%, 10.3 \%$, $8.2 \%$ and $10.4 \%$ for mc-Si glass module (165Wp), a-Si glass module ( $40 \mathrm{Wp}), \mathrm{pc}-\mathrm{Si}$ module $(105 \mathrm{Wp}), \mathrm{pc}-\mathrm{Si}$ module $(60 \mathrm{Wp})$ and PV-T $(180 \mathrm{Wp})$ respectively. Under the given outdoor conditions, the highest average PR of $85.2 \%$ was obtained for the mc-Si glass module (165Wp) exhibiting the best performance; the lowest average PR of 71.8 was observed in case of pc-Si module (60 Wp).

Table 3 Comparison between experimental and manufacturer's module efficiency

\begin{tabular}{|l||c|c|c|c|c|}
\hline Module technology & $\begin{array}{c}\text { mc-Si module } \\
\text { glass (165 Wp) }\end{array}$ & $\begin{array}{c}\text { a-Si module } \\
\text { glass (40 Wp) }\end{array}$ & $\begin{array}{c}\text { pc-Si module } \\
\text { (105Wp) }\end{array}$ & $\begin{array}{c}\text { pc-Si module } \\
\text { (60Wp) }\end{array}$ & $\begin{array}{c}\text { PV-T glazed } \\
\text { mc-Si (180 Wp) }\end{array}$ \\
\hline $\begin{array}{l}\text { Datasheet efficiency } \\
\text { (DE) (\%) }\end{array}$ & 10.3 & 5 & 12.7 & 10.6 & 12.6 \\
\hline $\begin{array}{l}\text { Measured efficiency } \\
\text { (ME) (\%) }\end{array}$ & 9.4 & 4.4 & 10.3 & 8.2 & 10.4 \\
\hline (DE-ME)/DE & $-8.7 \%$ & $-12 \%$ & $-18.9 \%$ & $-22.6 \%$ & $-17.5 \%$ \\
\hline
\end{tabular}

Table 4 Performance ratios (PR) of modules

\begin{tabular}{|c|c|c|c|c|c|}
\hline $\begin{array}{l}\text { Performance ratios } \\
\text { (PR) of modules }\end{array}$ & $\begin{array}{c}\text { mc-Si (glass) } \\
(165 \mathrm{Wp})\end{array}$ & $\begin{array}{l}\text { a-Si (glass) } \\
(40 \mathrm{Wp})\end{array}$ & $\begin{array}{c}\text { pc-Si } \\
(105 \mathrm{Wp})\end{array}$ & $\begin{array}{c}p c-S i \\
(60 \mathrm{Wp})\end{array}$ & $\begin{array}{c}\text { PV-T glazed mc-Si } \\
(180 \mathrm{Wp})\end{array}$ \\
\hline Minimum & 0.83 & 0.79 & 0.74 & 0.69 & 0.75 \\
\hline Maximum & 0.91 & 0.89 & 0.81 & 0.77 & 0.83 \\
\hline Average & $85.2 \%$ & $82.6 \%$ & $76.7 \%$ & $71.8 \%$ & $77.5 \%$ \\
\hline
\end{tabular}




\section{Acknowledgement}

This work was supported by the Stipendium Hungaricum Programme and the Mechanical Engineering Doctoral School, Szent István University, Gödöllő, Hungary.

\section{References}

ALMONACID, F. - RUS, C. - PEREZ-HIGUERAS, P. - HONTONA L. 2011. Calculation of the energy provided by a PV generator. Comparative study: conventional methods vs artificial neutral network. In Energy, vol. 36, pp. 375-384.

ATSU, D. - SERES, I. - FARKAS, I. 2017. Performance evaluation of solar photovoltaic modules under real conditions. In Book of Abstracts, $23^{\text {th }}$ Workshop on Energy and Environment, Gödöllö, Hungary, November 30-December 1, 2017, p. 20.

AYOMPE, L. M. - DUFFY, A. - MCCORMACK, S. J. - CONLON, M 2011. Measured performance of a $1.72 \mathrm{~kW}$ rooftop grid connected photovoltaic system in Ireland. In Energy Conversion and Management, vol. 52, no. 2, pp. 816-825.

BALASKA, A. - TAHRI, A. - TAHRI, F. - STAMBOULI, A. B. 2017 Performance assessment of five different module technologies under outdoor conditions in Algeria. In Renewable Energy, vol. 107, pp. 53-60

BASOGLU, M. E. - KAZDALOGLU, A. - ERFIDAN, T. - BILGIN, M. Z. CAKIR, B. 2015. Performance analysis of different photovoltaic module technologies under Izmit, Kocaeli climate conditions. In Renewable and Sustainable Energy Reviews, vol. 52, pp. 357-365. BILČÍK, M. - BOŽIKOVÁ, M. - PETROVIČ, A. - MALÍNEK, M. CVIKLOVIČ, V. - OLEJÁR, M. - ARDONOVÁ, V. 2018. Analysis of selected photovoltaic panels operating parameters as a function of partial shading and intensity of reflected radiation. In Acta Technologica Agriculturae, vol. 21, no. 1, pp. 14-17.

CAÑETE, C. - CARRETERO, J. - SIDRACH-DE-CARDONA, M. 2014 Energy performance of different photovoltaic module technologies under outdoor conditions. In Energy, vol. 65, pp. 295-302.
CARR, A. J. - PRYOR, T. 2004. A comparison of the performance of different PV module types in temperate climates. In Solar Energy, vol. 76, pp. 285-294.

CRISTINA, C. - JESUS, C. - MARIANO, S. 2014. Energy performance of different photovoltaic module technologies under outdoor conditions. In Energy, vol. 65, pp. 295-302.

DEL CUETO, J. 2002. Comparison of energy production and performance from flat plate photovoltaic module technologies deployed at fixed tilt. In Proceedings of the $29^{\text {th }}$ IEEE photovoltaic specialists conference (2002), pp. 1523-1526.

DUFFIE, J. A. - BECKMAN, W. A. 2006. Solar Engineering of Thermal Processes. New York, Wiley. 928 pp. ISBN 0-471-69867-9.

DURISCH, W. - BITNAR, B. J. - MAYOR, H. - KIESS, K. - LAM, J. 2007. Efficiency model for photovoltaic modules and demonstration of its application to energy yield estimation. In Solar Energy Materials and Solar Cells, vol. 91, pp. 79-84.

INTERNATIONAL ENERGY AGENCY (IEA). 2014. Technology Roadmap. Solar Photovoltaic Energy.

KING, R. R. - BHUSARI, D. - LARRABEE, D. - LIU, X. Q. - REHDER, E. EDMONDSON, K. - COTAL, H. - JONES, R. K. - ERMER, J. H. - FETZER, C. M. - LAW, D. C. - KARAM, N. H. 2012. Solar cell generations over 40\% efficiency. In Progress in Photovoltaics: Research and Applications, vol. 20, pp. 801-815.

SHARMA, V. - KUMAR, A. - SASTRY, O. - CHANDEL, S. 2013. Performance assessment of different solar photovoltaic technologies under similar outdoor conditions. In Energy, vol. 58, pp. 511-518.

SINGH, G. 2013. Solar power generation by PV (photovoltaic) technology: a review. In Energy, vol. 53, pp. 1-13.

YE, J.Y. - REINDL, T. - ABERLE, A. G. - WALSH, T. M. 2014. Performance degradation of various PV module technologies in tropical Singapore. In IEEE Journal of Photovoltaics, vol. 4, pp. 1288-1294. 